\title{
Use of Potential Plant Leaves as Ingredient in Fish Feed-A Review
}

\author{
M.S. Dorothy ${ }^{1}$, Sudhanshu Raman ${ }^{1}$, Vipin Nautiyal ${ }^{1}$, Khushvir Singh ${ }^{2}$, \\ T. Yogananda ${ }^{3}$ and Makamguang Kamei ${ }^{4}$
}

\author{
${ }^{1}$ National Fisheries Development Board, Hyderabad-500052, India \\ ${ }^{2}$ Krishi Vigyan Kendra, Barnala, Guru Angad Dev Veterinary and Animal Sciences \\ University, Ludhiana-141004, India \\ ${ }^{3}$ Assistant Director of Fisheries, Channapatna-562160, India \\ ${ }^{4}$ Central Institute of Fisheries Education, Mumbai-400061, India
}

*Corresponding author

\section{A B S T R A C T}

\section{Keywords}

Aquaculture, Cost effectiveness, Fish feed, Plant protein, Sustainability

\section{Article Info}

Accepted:

04 June 2018

Available Online:

10 July 2018
Fish feed plays an important role in the growth of the aquaculture industry. Use of plant protein source in the feed industry has been in practice for various advantages such as sustainability, availability, cost effectiveness etc. Terrestrial plant leaves of turi, drumstick, ipil-ipil, alfalfa, mulberry, sweet potato, cassava, cucumber, squash, broad bean, papaya, white cowpea, green mung-bean, jackfruit, mexican fire plant, cocoyam, black jack, banana, akee etc. and aquatic plant leaves of azolla, water hyacinth, duckweeds, water lettuce, Indian stargrass, white snow flake, duck lettuce, bur-reed, water fern etc. have been used in the fish feed industry. They are used in the form of fresh and raw, dried, powdered, cooked, fermented, concentrates etc. It is use as direct feed (in case of herbivorous fishes), supplementary or partial replacement to fish meal in formulation of fish feed. The paper is an attempt to make extensive review on potential use of various plant leaves as ingredient in fish feed industry.

\section{Introduction}

With the rapid growth in the aquaculture sector in the recent years, the demand for quality fish feed is continuously increasing. Providing quality fish feed became a prime aim of every aquaculturist. Though fish feed devours around $50 \%$ of the production cost, yet it plays the pivotal role in the production and yield outcome (Mzengereza et al., 2014). With the increase in demand, the price of feed increased simultaneously. One main reason for the rise in the cost price of fish feed is due to the rise in demand of fish meal which remains the core of the protein supply of the feed. The demand for fish meal is not just increasing but the supply of it is also dwindling with stagnating marine catches and alternative use of it for livestock and human consumption (Fasakin et al., 1999). So, the quest for possible alternative protein sources to replace (complete/partial) fish meal in the feed became paramount (Magouz et al., 2008). As animal protein sources are mostly expensive 
and not easily available, plant sources are considered to be one possible alternative that can be used in fish feed without compromising the nutritional quality of the feed (El-Sayed, 1999; Francis et al., 2012). Moreover, use of cheaper and locally available plant sources to substitute the expensive fish meals would mean reduction in the production cost and thereby enhance the profit (Osman et al., 1996, Munguti et al., 2006).

The prime consideration of selecting a fish feed ingredients and formulation of the feed is the digestibility, palatability and acceptability by the fish, availability and cost of the ingredients (Lovell, 1991; Rodriguez et al., 1996; De Silva and Anderson 1994). Incorporation of plant sources in fish feed generally has its limitation due to low protein content, presences of anti-nutritional factors such as alkaloids, glycosides, oxalic acids, phytates, protease inhibitors, haematoglutinin, saponegin, momosine, cyanoglycosides etc. and their imbalances in some essential amino acids, fatty acids and micronutrients (Wee, 1991; Abowei et al., 2011). The potential of the feedstuffs to be used in fish diets can be established based on their proximate chemical composition (Mzengereza et al., 2014). Efforts are made to remove the anti-nutritional factors in the plant sources (Anderson and Wolf, 1995; Bairagi et al., 2002). Before incorporation into diets and to reduce antinutritional factors the leaf meals were soaked in water, dried, and ground to a small particle size (Lochmann et al., 2011). In fish feed many research has been done on use of soybean, rapeseed (canola) meal, cottonseed meal, sunflower seed meal, wheat and corn gluten, peanut meal, moringa leaves meals etc. (Makkar and Becker, 1996; Francis et al., 2012; Egwui et al., 2013; Mondal and Payra, 2015). The paper attempts an extensive review of the potential of various plant protein sources that can be used as ingredients in formulating fish feed in the aquaculture industry.
Use of alternative plant protein sources in fish feed

Plant products contain huge amount protein, different amino acid and fatty acids which are not available in animal protein (Mondal and Payra, 2015). Use of plant protein in fish feed industry has been tried for various commercial culture fish species as the formulation of feed is specific to species based on their specific requirements. The advantages lie not only in the availability and economic benefits but also that these plant products also have less amount of phosphate and nitrogen than animal protein, therefore, reducing the chances of eutrophication of pond. Vhanalakar, (2009) reported that plant source feedstuffs suitable for fish feed formulation are pods, seeds, leaves, fruits of certain plants, grains, oilcakes like linseed, safflower, sunflower, soybean, roots, cereals and cereal by-products, broken rice, rice polish, tubers of sweet potato, wheat bran, maize, cassava, sorghum, etc. In fish feed industry Grasses, vegetables, aquatic weeds, plant's leaves, stems, seeds and seed extracts are commonly used (Mondal and Payra, 2015). Leaf meals for fish feed are often derived from plants of terrestrial as well as of aquatic origins (Bardach et al., 1972). The discussion has been thus grouped into two categories such as:

1. leaf meals derived from terrestrial plants

2. leaf meals derived from aquatic plants

\section{Leaf meals derived from terrestrial plants}

\section{Turi leaf meal}

Sesbania grandiflora or turi is a short-lived fodder shrub or small plant belonging widely distributed and cultivated throughout tropical Africa and Asia (Patel, 1966). They grow rapidly and can tolerate wide temperature ranges, waterlogging, acidic and saline soils 
(Hansen and Munns, 1985; Gutteridge and Shelton, 1998). The leaves have high protein content and low fibre and often used as fodder, green manure or as a feed ingredient in cattle and aqua feed industry (Onim et al., 1987; Panda et al., 1988). Sesbania is a good source of essential fatty acids but deficient in essential amino acids except for leucine, tryptophan and histidine (Hossain and Becker, 2001). The crude protein content of turi leaf is reported to be higher than other conventional legumes like chickpea, mungbean and cowpea (Francis et al., 2012). Its leaves were reported to contain 22-30\% crude protein (Kaitho et al., 1998). Use of its leaf meal in the feed of Labeo rohita reported enhanced growth (Devi et al., 1997). Addition of turi leaf flours in feed ration promoted growth in black tilapia, Orechromis niloticus (Firmani et al., 2015).

\section{Moringa leaf meal}

The fresh leaves of Moringa oleifera or 'drumstick' are a highly nutritious supplement to the diet of plant-eating fish such as tilapia, barbs, fancy carps etc. (Yuangsoi and Masumoto, 2012). They harbor rich protein, lipids, vitamins and minerals and hence the leaves, kernel and pods are often used in aquaculture feed industry (Egwui et al., 2013). Makkar and Becker (1997) reported that the leaves of this plant contain $23 \%$ crude protein while Egwui et al., (2013) reported $26.4 \%$. Lochmann et al., (2011) suggested that drying, soaking and grounding the leaf meals into powder could reduce the antinutritional factors. The leaf is free from antinutritional factors except for saponins and phenols (Egwui et al., 2013). Fresh Moringa leaves provide additional protein, vitamins and amino acid such as methionine, cystine, tryptophan that can improve the growth and health of fish (Makkar and Becker, 1996). To partially replace conventional diets Moringa leaves has been successfully used without compromising the growth performance of Nile tilapia (Oreochromis niloticus) (Afuang et al., 2003; Richter et al., 2003; Tagwireyi et al., 2012), Cyprinus carpio (Yuangsoi and Masumoto, 2012) and Clarias gariepinus (Nsofor et al., 2012). They also reported that the optimum inclusion level of $20 \%$ moringa leaves can be used in the formulation diet for catfish C. gariepinus. Afuang and co-workers (2003) also reported that solvent extracts of moringa leaves can replace $30 \%$ of fish meal in $O$. niloticus diets. However, in contrast, Hlophe and Moyo (2014) reported that adding moringa leaf meals to diet of Tilapia rendalli even at the $25 \%$ inclusion level was expensive and resulted in compromised growth and health which may be due to the presence of tannins and polyphenols. To substitute $10 \%$ of dietary protein steam heated moringa leaf meal can be used without a reduction in growth performance in Nile tilapia fry (Tagwireyi et al., 2012).

\section{Subabul leaf meal}

Leucaena leucocephala, commonly called as ipil-ipil is a fast growing and droughtresistant tropical leguminous plant that is often used in the animal feed industry (Osman et al., 1996). The leaf contains more than $20 \%$ crude protein (on a dry matter basis) and seed has $\alpha$-carotene with rich amino acid profile (Kale, 1987). However, its use has been limited due to the presence of a toxic, nonprotein amino acid, mimosine which retards the growth of animal when consume in high quantity (Sotolu and Faturoti, 2008). However, Pantastico and Baldia (1979) reported improved growth performances in tilapia on inclusion of leucaena leaf meal in diet. Leucaena is a good feed ingredient for small fishes such as mollies, topminnows (Poecilia spp.) and freshwater prawn, Macrobrachium rosenbergii (D'Mello and Acamovic, 1989). The inclusion of 33 to $100 \%$ leucaena leaf meal in the diet of Oreochromis niloticus fingerlings enhanced fish growth in the cages (Cruz and Laudencia, 1977). 
Incorporation of L. leucaena leaf meal in the diets of $O$. niloticus at $12.5 \%$ inclusion did not affect growth, however, at high levels of inclusion, $25 \%$ or more, the growth was adversely affected (Santiago et al., 1988). Moreover, Sotolu and Faturoti (2008) also revealed that the seed has high nutrient content with good protein source that enhanced the growth and survival of Clarias gariepinus.

\section{Alfalfa leaf meal}

Medicago sativa or alfalfa is a flowering plant grown throughout the world mostly as forage for cattle due to its high protein content and balanced amino acid profile, vitamins, and carotenoids (Olvera-Novoa et al., 1990; Vhanalakar and Muley, 2015). Both fresh and dried leaves have experimented in the feed of tilapia (Olvera-Novoa et al., 1990). Chatzifotis et. al., (2006) also reported that incorporating alfalfa protein concentrate in seabream feeds promotes growth. OlveraNovoa et al., (1990) reported that inclusion of alfalfa leaf protein upto $35 \%$ inclusion level can be used in feeds of tilapia without compromising the growth and survival of the fish. It has been reported enhanced growth and survival of common carp and mrigal coupled with an increase in protein and lipid content when alfalfa leaf meals are included upto $40 \%$ and $30 \%$ respectively in the diet (Vhanalakar, 2009; Vhanalakar and Muley, 2015). Use of dehydrated alfalfa leaves in the diet of tilapia was also reported (Yosif et al., 1994). Most of the researchers recommended low replacement level. Ali et al., (2003) suggested only up to $5 \%$ inclusion level. Sklan et. al. (2004) reported that complete replacement may hamper the growth performance.

\section{Mulberry leaf meal}

Morus alba or mulberry leaves which are grown for silkworm industry is often used in fish feed formulations due to high protein content and mineral elements (Bag et al., 2012). The limitation of its use is due to deficiencies in essential amino acids, the presence of anti-nutritional factors and complex carbohydrates (NRC, 1993). Bairagi et al., (2002) recommended that fermentation could be a simple and cheap way to reduce the anti-nutritional factors in it. Mondal et al., (2012) reported that mulberry leaf meal could be a potential protein source in the diet of Labeo bata. Cruz and Laudencia (1978) used mulberry leaf meal for Nile tilapia resulting enhanced growth and lower FCR at $60 \%$ inclusion in combination with $40 \%$ rice bran. Bag et al., (2012) also reported this leaf meal incorporation in stinging catfish diet enhanced growth and survival, higher acceptance by fish and improved immunity against common disease.

\section{Sweet potato leaves}

Ipomoea batatas, sweet potato is widely culture around the world and is also one of the most important food crops in tropical areas (Le Van An, 2004). The leaves have been used as forage for the cattle due to high protein and fibre content (Antia et al., 2006; Adewolu, 2008). Preston (2006) also reported that the crude protein contents ranging from 26.5 to $32.5 \%$ in leaves of sweet potato. Adewolu (2008), in his review, mentioned that the leaf meal of the plant has $26-33 \%$ crude protein, high amino acid, mineral and vitamin content. He also cited that the advantage of using this plant meal in fish feed is because this plant leaves can be harvested many times a year thereby making the availability easier and cheaper. The presence of anti-nutritional factors such as invertase and protease inhibitors can be removed by oven or sun-drying, boiling or steaming and grinding prior to inclusion in fish feeds thereby increasing the palatability (Oyenuga, 1968; Adewolu, 2008). Experiments on Tilapia zilli resulted that sweet potato leaf 
meal could be included up to $15 \%$ level in diets without compromising the growth and feed efficiency (Adewolu, 2008).

\section{Cassava leaf meal}

Manihot esculenta, cassava leaf is widely used as forage for animals due to its palatability and high protein content (Phuc et al., 2000). Ravidran (1991) reported that the leaf meal of cassava has $16.7-39.9 \%$ crude protein and mineral content. To reduce the impact of anti-nutritional factors such as cyanogenic glycosides and tannins, the leaves can be soaked and sundried (Hassan et al., 2017). Ng and Wee (1989) suggested that cassava leaf meal can be potentially used in the diet of Nile tilapia without compromising the growth and survival of the fish. Hassan et al., (2017) reported that this leaf meal can be used upto $20 \%$ replacement in the diets for African catfish without negatively impacting the growth and nutrient utilization.

\section{Other terrestrial plant leaf meals}

Use of other leaf meals from other terrestrial plants such as cucumber, squash and broad bean leaves were experimented by Magouz and co-workers (Magouz et al., 2008). They reported crude protein content level of $26.87 \%, 21.11 \%$ and $27.45 \%$ in cucumber, squash and broad bean leaves respectively and can be effectively used in the diet of Nile tilapia. 30\% inclusion of duckweed, Spirodela polyrrhiza in the diet of $O$. niloticus support growth (Fasakin et al., 1999). Eusebio and Coloso (1998) also reported in diet of juvenile Penaeus indicus use of papaya leaf, white cowpea leaf and green mung-bean leaf. They, however, reported that shrimp fed with green mung-bean resulted lower survival. Obwanga (2010) reported that the presence of papain in papaya leaf that helps in protein digestibility promotes fish growth and he further reported that papaya leaf meal may be used to replace
$100 \%$ fish meal in the diet of $\mathrm{O}$. niloticus. Belal (1999) reported upto $40 \%$ replacement of fish meal with sarliconia leaf meal in the diet of Nile Tilapia without compromising its growth. There are also report of using jackfruit leaf, mexican fire plant leaf, cocoyam leaf, black jack leaf, banana leaf, akee leaf as a potential protein source to replace fish meal in the diet of tilapia (Mzengereza et al., 2014).

\section{Leaf meals derived from aquatic plants}

Wersal and Madsen (2012) defined aquatic plant as the macrophyte -plants that are visible to the unaided eye. They also reported the various use of macrophytes viz. food for human, medicinal use, livestock fodder, fertilizer, compost, mulch, bioremediation etc. Use of aquatic plant leaves in the fish diet due to high nutrient content is well documented by various authors (Chiayvareesajja et al., 1989; Sheeno and Sahu, 2006; Hasan and Rina, 2009; Wersal and Madsen, 2012). The advantage of usage includes costeffectiveness, ease of availability, nutritional contents etc. (Ray and Das, 1995). Moreover, the aquatic weed that grows in the same water body can be converted into useful feed ingredients (Edwards et al., 1992; Gavina, 1994).

Herbivorous and Omnivorous fish such as grass carps, common carp, tilapia, amur carp etc. are used directly in the weed infested ponds to graze on the weeds (Le Mare, 1952; Ling, 1960; Mehta and Sharma, 1972; Legner, 1975). The cost of production of aqua feed can be reduced using this eco-friendly and sustainable resource (Gangdhar et al., 2014). Ray and Das (1995) also suggested that aquatic which could be used as an alternative protein source in the fish diet. Sheeno and Sahu (2006) used various aquatic weeds as a partial or complete replacement of fish meal protein. 


\section{Azolla}

Mosquito plant or Azolla is an aquatic freefloating fern that has the ability to fix and assimilate atmospheric nitrogen. It grows rapidly and has the potential to double its weight in 2-3 days. It is also often referred to as "super plant" due to its high nutrient content such as essential amino acids, vitamins (vitamin A, vitamin B12 and BetaCarotene), growth promoter intermediaries and minerals like calcium, phosphorous, potassium, ferrous, copper, magnesium etc. Azolla contains high protein (19-31\%) and low lignin which makes it a desirable ingredient in animal feed industry (Sheeno and Sahu, 2006). Azolla pinnata has been reported to be a potential protein source in fish feed industry (Micha et al., 1988). However, some researchers reported that feeding fresh or dried Azolla directly to the fish may result in poor growth (Antoine et al., 1986; Micha et al., 1988). Gangdhar et al., (2014) gave an account of improved feed utilization in Tilapia mossambica and increased growth in Rohu, Nile tilapia, Common carp, Silver carp and Mrigal when Azolla is incorporated in the diet of the fish. Higher inclusion of Azolla protein concentrate beyond $50 \%$ reduced the protein utilization capacity in the diet of Labeo rohita fry (Sheeno and Sahu, 2006). Some researchers are in the view that Azolla powder should be used to replace only upto $25 \%$ fishmeal in tilapia (El-Sayeed, 1992), in Etroplus suratensis (Joseph et al., 1994), 45\% in Cirrhinus mrigala fry (Gangdhar et al., 2014), 42\% in Oreochromis niloticus fry (Santiago et al., 1988), respectively.

\section{Water hyacinth}

Water hyacinth, Eichhornia crassipes is a rapid growing, herbaceous, free-floating aquatic plant native to amazon basin. This plant is known to be "the world's worst aquatic weed" due to their invasive nature and the culture of it is restricted in some part of the world. Lareo and Bressani (1982) reported that fresh and composted water hyacinth is used as feed for various animals. They reported $38 \%$ protein content in the dry matter of the leaves and 17-26\% minerals. Use of water hyacinth as feedstuffs for fish diets for large scale was not recommended by many researchers unless the hyacinths are composted or fermented (Liang and Lovell, 1971; Wersal and Madsen, 2012). El-Sayed (2003) reported that fermented water hyacinth can be incorporated into the diet of Nile tilapia upto $25 \%$ inclusion level. He suggested fermentation to enhance the palatability and better utilization by the fish. Edwards and his co-workers (1985) also recommended composting of water hyacinth before incorporating into fish diet. They reported that composted water hyacinth can be used to replace fishmeal upto $75 \%$ replacement for diet of Nile tilapia. Saint-Paul et al (1981) revealed that inclusion of water hyacinth meal (dried and grounded) upto $18.9 \%$ inclusion level does not compromise the growth and survival of Matrincha fish. They, however, suggested that high-level inclusion may not be recommended as the presence of tannin in the plant interferes the protein digestibility.

\section{Duckweeds}

Duckweeds or water lens is a floating aquatic plant that grows luxuriantly in freshwater bodies in the tropical and subtropical areas (Majid, 1986). It consists of four genera viz. Lemna, Spirodela, Wolfilla and Wolffiella. Duckweeds (dry matter) contains 15-43\% crude protein, 5-30\% fibres, 5\% lipids and often used in animal feed industry (Leng et al., 1995; Cheng and Stomp, 2009; Mohapatra and Patra, 2013). They also suggested use of duckweed in fish diet due to presence of high protein, trace minerals, $\mathrm{K}$ and $\mathrm{P}$ and pigments, particularly carotene and xanthophyll. Fresh 
duckweed has been successfully used as feedstuffs for common carp, Thai sharputi, raj puti, silver carp, mrigal and tilapia (Leng et al., 1995; Kabir et al., 2009).

Mohapatra and Patra (2013) experimented on inclusion of duckweed in the diet of common carp. They arrived that fishmeal may not be replaceable by duckweed meal but can be used to supplement the diet upto $15 \%$ inclusion level to reduce the cost without compromising the growth. Das and Ray (1989) reported that dried duckweed (Lemna polyrhiza) could be potentially used as a feed ingredient for Labeo rohita fingerlings without affecting the growth and survival of the fish. Yilmaz et al., (2005) recommended fermentation of lemna leaf meal for fish feed formulation. They also reported that duckweed can substitute upto $20 \%$ of commercial fish meal in the feed of common carp. Fasakin et. al.,1999 outline that incorporation of solar-dried duckweed (Spirodela polyrrhiza) upto $30 \%$ fish meal replacement in diet of Nile tilapia enhance good growth and is cost effective. Mbagwu et al., (1990) reported that enhanced growth and survival of mango tilapia fingerlings fed with diet containing 10\% duckweed (Lemna paucicostata).

\section{Other aquatic plant leaf}

Extensive review on literature reveals that aquatic plants are an excellent source of nutrients that can be potentially used in formulation of fish diet (Hillman and Culley, 1978; Bahnasy et al., 2016). Common aquatic plants like water lettuce (Pistia stratiotes), Indian stargrass (Hydrilla verticillata), white snow flake (Nymphoides cristatum), ducklettuce (Ottelia alismoides), bur-reed (Sparganium spp), Sedges (Carex riparia) and water ferns (Salvinia cuculata) have been experimented in diet of fish (Zolotova and Khromov, 1970; Hajra, 1985; Patnaik et al.,
1991; Ray and Das, 1994). Submerged aquatic plants like chara, hornwort, oxygen weed, water velvet, water milfoil and pondweeds (Elodea) were used to feed the fishes as fresh or in dried powder form incorporated in diet formulation (Stott and Orr, 1970). Use of unicellular microalgae Chlorella, Scendesmus, Spirogyra and Spirulina in the fish diet was also reported (Sheeno and Sahu, 2006). Use of hornwort in fish diet reportedly resulted in poor growth which might be due to its poor digestibility (Tantikitti et al., 1988).

In conclusion, aquaculture is one of the fastest growing food sector in the world. With the increase in demand of fish, aquaculture has forged into heavy intensification. Nutritionally imbalance or poor quality feed would potentially impair the growth and productivity in such highly intensive system. Hence, to ensure that the intensively stocked fishes are fed with nutritional balance diet, the demand for formulated species-specific quality feed escalated in recent years. The cost of fish meal, which has been the chief protein source in feed formulation continues to heightened while the availability declined. Thus, the quest for other alternative protein source to replace fishmeal becomes imperative in the sector. However, complete replacement of fishmeal using animal protein source are limited and not cost effective or sustainable, exploration of unconventional plant sources became paramount as alternative protein source. Feedstuffs with high carbohydrate can be preferably used as it actuates the protein sparing effect making the feed more cost effective (Hidalgo et al., 1993). It is of the opinion that use of plant protein source could ease the availability of feedstuff and reduce the feed cost (Rumsey, 1993). With greater research and experimentation, the limitations of using plant sourced feedstuffs such as the presence of anti-nutritional factors, varying amino acid 
contents etc. have been minimized by implying various techniques such as soaking of the ingredients, heating, drying, disintegration to finer particles or concentrates etc. Hence, many of the plant leaves are used in fish feed formulation as protein source most of which is a partial replacement of fish meal. Use of plant protein source in feed industry is sustainable, environmental friendly and cost effective.

\section{References}

Abowei, J. F. N. and Ekubo, A. T., 2011. A review of conventional and unconventional feeds in fish nutrition. British Journal of Pharmacology and Toxicology, 2(4):179-191.

Adewolu, M.A., 2008. Potentials of sweet potato (Ipomoea batatas) leaf meal as dietary ingredient for Tilapia zilli fingerlings. Pakistan Journal of Nutrition, 7(3):444-449.

Afuang, W., Siddhuraju, P. and Becker, K. 2003. Comparative nutritional evaluation of raw, methanol extracted residues and methanol extracts of moringa (Moringa oleifera Lam.) leaves on growth performance and feed utilization in Nile tilapia (Oreochromis niloticus L.). Aquaculture Research. 34, 11471159.

Ali, A., Al-Asgah, N. A., Al-Ogaily, S. M and Ali, S. 2003. Effect of feeding different levels of alfalfa meal on the growth performance and body composition of Nile tilapia (Oreochromis niloticus) fingerlings. Asian fisheries science, 16(1/2): 5968.

An, L.V. and Lindberg, J.E., 2004. Ensiling of sweet potato leaves (Ipomoea batatas (L.) Lam) and the nutritive value of sweet potato leaf silage for growing pigs. Asian-australasian journal of animal sciences, 17(4):497-503.

Anderson, R.L. and Wolf, W.J., 1995. Compositional changes in trypsin inhibitors, phytic acid, saponins and isoflavones related to soybean processing. The Journal of nutrition, 125(suppl_3), pp.581S-588S.

Antial, B.S., Akpanz, E.J., Okonl, P.A. and Umorenl, I.U., 2006. Nutritive and anti-nutritive evaluation of sweet potatoes. Pak. J. Nutr, 5(2):166-168.

Antoine, T., Carraro, S., Micha, J.C. and Van Hove, C., 1986. Comparative appetency for azolla of cichlasoma and oreochromis (tilapia). Aquaculture, 53(2):95-99.

Bag, M.P., Ghorai, M., Mahapatra, S.C., Rao, P.S. and Pal, H., 2012. Evaluation of Mulberry (Morus alba, Linn.) leaf meal as a complete diet for sting fish (Heteropneustes fossilis, Bloch.). International Journal of Pharmacy \& Life Sciences, 3(9).

Bahnasy, S.A., Kamel, G.A. and Saaffan, S.E., 2016. The Nutritive Value of Aquatic Plants and Their Utilization in Fish and Animal Feed. Arab Journal of Science and Research Publishing, 2(2):1-8.

Bairagi, A., Ghosh, K.S., Sen, S.K. and Ray, A.K., 2002. Duckweed (Lemna polyrhiza) leaf meal as a source of feedstuff in formulated diets for rohu (Labeo rohita Ham.) fingerlings after fermentation with a fish intestinal bacterium. Bioresource technology, 85(1):17-24.

Bardach, J.E., Ryther, J.H. and McLarney, W.O., 1972. Aquaculture. The farming and husbandry of freshwater and marine organisms. John Wiley \& Sons, Inc..

Belal, I.E. and Al- Dosari, M., 1999. Replacement of fish meal with Salicornia meal in feeds for Nile tilapia Oreochromis niloticus. Journal 
of the World Aquaculture Society, 30(2): 285-289.

Chatzifotis. S., Esteban, A.G and Divanach, P., 2006. Fishmeal replacement by alfalfa protein concentrates in sharp snout sea bream Diplodus puntazzo. Fish. Sci., 72: 1313-1315

Cheng, J.J. and Stomp, A.M., 2009. Growing duckweed to recover nutrients from wastewaters and for production of fuel ethanol and animal feed. Clean-Soil, Air, Water, 37(1):17-26.

Chiayvareesajja, S., C. Wongwit and R. Tansakul, 1989. Cage Culture of Tilapia (Oreochromis niloticus) Using Aquatic Weed Based Pellet. In: Second Asian Fisheries Forum, Hirano, R. and I. Hanyu (Eds.). Tokoyo, Japan: 17-22.

Cruz, E.M. and L.L. Laudencia, 1977. Protein requirement of Tilapia mossambica fingerlings. Kalikasan. Phill. J. Biol., 6: $177-182$.

Cruz, E.M. and Laudencia, I.L., 1978. Screening of feedstuffs as ingredients in the rations of Nile tilapia [freshwater fish, in the Philippines]. Philippine Journal of Biology.

D'Mello, J.P.F and Acamovic, T., 1989, Leucaena leucocephala in poultry nutrition. A review, Animal Feed Science and Technology, 26:1-28.

Das, I. and Ray, A.K., 1989. Growth performance of Indian major carps Labeo rohita (Ham.) on duckweed incorporated pelleted feed: a preliminary study. J. Inland Fish, 21(1):1-6.

De Silva, S.S. and Anderson, T.A., 1994. Fish nutrition in aquaculture (Vol. 1). Springer Science \& Business Media.

Devi, C., Vuayaraghavan, S. and Srinivasulu, C., 1997. Sesbania Sesban and Cicer Arietinum Leafmeal as Dietary Ingredients in the Feeding of Fish. Indian Journal of Animal Nutrition,
14(3):167-170.

Edwards, P., Hassan, M.S., Chao, C.H. and Pacharaprakiti, C., 1992. Cultivation of duckweeds in septage-loaded earthen ponds. Bioresource technology, 40(2):109-117.

Edwards, P., Kamal, M. and Wee, K.L., 1985. Incorporation of composted and dried water hyacinth in pelleted feed for the tilapia Oreochromis niloticus (Peters). Aquaculture Research, 16(3):233-248.

Egwui, P.C., Mgbenka, B.O. and Ezeonyejiaku, C.D., 2013. Moringa plant and it use as feed in aquaculture development: a review. Animal Research International, 10(1):1672.

El-Sayed, A. F., 1999. Alternative dietary protein sources for farmed tilapia, Oreochromis spp. Aquaculture, 179(1):149-168.

El-Sayed, A. F., 1992. Effects of substituting fish meal with Azolla pinnata in practical diets for fingerling and adult Nile tilapia, Oreochromis niloticus (L.). Aquaculture Research, 23(2):167-173.

El-Sayed, A.F., 2003. Effects of fermentation methods on the nutritive value of water hyacinth for Nile tilapia Oreochromis niloticus (L.) fingerlings. Aquaculture, 218(1): 471-478.

Eusebio, P.S. and Coloso, R.M., 1998. Evaluation of leguminous seed meals and leaf meals as plant protein sources in diets for juvenile Penaeus indicus. The Israeli Journal of AquacultureBamidgeh, 50(2): 47-54.

Fasakin, E. A., Balogun, A. M. and Fasuru, B. E., 1999. Use of duckweed, Spirodela polyrrhiza L. Schleiden, as a protein feedstuff in practical diets for tilapia, Oreochromis niloticus L. Aquaculture Research, 30(5): 313-318.

Firmani, U., Cahyoko, Y. and Mustikoweni, M., 2015. Utilization of Turi Leaf Flour in Feed (Sesbania grandiflora 
Pers.) on Growth of Black Nile Tilapia (Orechromis niloticus)., 16(2): 69-72.

Francis, G., Makkar, H.P. and Becker, K., 2012. Products from little researched plants as aquaculture feed ingredients. Agrippa-FAO online Journal (www. fao. org/Agrippa)

Gangadhar, B., Sridhar, N., Saurabh, S., Raghavendra, C.H., Hemaprasanth, K.P., Raghunath, M.R. and Jayasankar, P., 2014. Growth Response of Cirrhinus mrigala Fry to Azolla (Azolla pinnata)-incorporated Diets. Fishery Technology, 51(3).

Gavina, L.D., 1994. Pig-duck-fish-azolla integration in La Union, Philippines. Naga, the ICLARM Quarterly, 17(2): $18-20$.

Hajra, A., 1985. Biochemical evaluation of common land grass as feed for grass carp, Ctenopharyngodon idella (Val.), in the tropics. Aquaculture, 47(4): 293-298.

Hansen, E.H. and Munns, D.N., 1985. Screening of Sesbania species for $\mathrm{NaCl}$ tolerance. Nitrogen Fixing Tree Research Reports, 3: 60-61.

Hasan, M.R. and Rina, C., 2009. Use of algae and aquatic macrophytes as feed in small-scale aquaculture: a review (No. 531). Food and Agriculture Organization of the United Nations (FAO).

Hassan M.,Wakil U.B and Gamawa A.I., 2017. Effects of Cassava Leaf Meal on Growth Performance and Nutrient Utilization of African Catfish in the Semi-Arid Zone of Nigeria. International Journal of Science and Technology, 6 (2): 689-693.

Hidalgo, M.C., Sanz, A., Gallego, M.G., Suarez, M.D. and De la Higuera, M., 1993. Feeding of the European eel Anguilla anguilla. I. Influence of dietary carbohydrate level.
Comparative Biochemistry and Physiology Part A: Physiology, 105(1): 165-169.

Hillman, W.S. and Culley, D.D., 1978. The uses of duckweed: The rapid growth, nutritional value, and high biomass productivity of these floating plants suggest their use in water treatment, as feed crops, and in energy-efficient farming. American Scientist, 66(4): 442-451.

Hlophe, S.N. and Moyo, N.A.G., 2014. A comparative study on the use of Pennisetum clandestinum and Moringa oleifera as protein sources in the diet of the herbivorous Tilapia rendalli. Aquaculture international, 22(4):1245-1262.

Hossain, M.A. and Becker, K., 2001. Nutritive value and antinutritional factors in different varieties of Sesbania seeds and their morphological fractions. Food Chemistry, 73(4): 421-431.

Joseph, A., P.M. Sherief and T. James, 1994. Effect of different dietary inclusion levels of Azolla pinnata on the growth, food conversion and muscle composition of Etroplus suratensis (Bloch). J. Aquacul. Trop., 9: 87-94.

Kabir, A.N.M.A., Hossain, M.A. and Rahman, M.S., 2009. Use of duckweed as feed for fishes in polyculture. Journal of Agriculture \& Rural Development, 7(1): 157-160.

Kaitho, R. J.; Umunna, N. N.; Nsahlai, I. V.; Tamminga, S.; Bruchem, J. van, 1998. Effect of feeding graded levels of Leucaena leucocephala, Leucaena pallida, Sesbania sesban and Chamaecytisus palmensis supplements to teff straw given to Ethiopian highland sheep.. Anim. Feed Sci. Technol., 72 (3-4): 355-366

Kale, A.U., 1987. Nutritive value of Leucaena leucocephala (subabul). Ph.D thesis, 
Submitted to the University of Bombay, India.

Lareo, L. and Bressani, R., 1982. Possible utilization of the water hyacinth in nutrition and industry. Food and Nutrition Bulletin, 4(4): 60-64.

Le Mare, D.W., 1952 Pig rearing, fish farming and vegetable growing. Malay.Agric.J., 35(3): 156-66.

Legner, E., Hauser, W., Fisher, T. and Meiived, R., 1975. Biological aquatic weed control by fish in the lower Sonoran Desert of California. California agriculture, 29(11): 8-10.

Leng, R.A., Stambolie, J.H. and Bell, R., 1995. Duckweed-a potential highprotein feed resource for domestic animals and fish. Livestock Research for Rural Development, 7(1): 36.

Liang, J.K. and Lovell, R.T., 1971. Nutritional value of water hyacinth in channel catfish feeds. Hyacinth Control J, 9(1): 40-44.

Ling, S.W. 1960. Control of aquatic vegetation. In Lectures presented at the Third International Inland Fisheries Training Centre, Bogor, Indonesia, 31 October-10 December 1955 , conducted by the Government of Indonesia and FAO with the cooperation of IPFC. Vol.1. Rome, FAO (3.23):12.

Lochmann, R., Engle, C., Kasiga, T., Chenyambuga, S.W., Shighulu, H., Madalla, N., Mnembuka, B.V. and Quagrainie, K., 2011. Develop Feeding Strategies for Moringa Oleifera and Leucaena Leucocephala as Protein Sources in Tilapia Diets.

Lovell, R.T., 1991. Nutrition of aquaculture species. Journal of Animal Science, 69(10): 4193-4200.

Magouz, F.I., El-Gendi, M.O., Salem, M.F.I. and Elazab, A.A., 2008, October. Use of cucumber, squash and broad bean leaves as non-conventional plant protein sources in Nile tilapia (Oreochromis niloticus) diet. In 8th International Symposium on Tilapia in Aquaculture. pp. 847-859.

Majid, F.Z., 1986. Aquatic weeds. Utility and development. Agro Botanical Publishers.

Makkar, H.P.S. and Becker, K., 1996. Nutrional value and antinutritional components of whole and ethanol extracted Moringa oleifera leaves. Animal feed science and technology, 63(1-4): 211-228.

Makkar, H.P.S., Becker, K., 1997. Nutrients and antiquality factors in different morphological parts of the Moringa oleifera tree. Journal of Agricultural Science, Cambridge 128: 311-322.

Mbagwu, I.G., Okoye, F.C. and Adeniji, H.A., 1990. Studies on the use of Duckweed (Lemna paucicostata Hegelm) as fish food.

Mehta, I. and Sharma R.K., 1972, Control of aquatic weeds by the white amur in Rajasthan, India. Hyacinth Control J., 10:16-9.

Micha, J.C., Antoine, T., Wery, P. and Van Hove, C., 1988. Growth, ingestion capacity, comparative appetency and biochemical composition of Oreochromis niloticus and Tilapia rendalli fed with Azolla. In Second International Symposium on Tilapia in Aquaculture. ICLARM Conference Proceedings (pp. 347-355). Bangkok: Department of Fisheries.

Mohapatra, S.B. and Patra, A.K., 2013. Effect of Partial Replacement of Fishmeal with Duck Weed (Lemna minor) feed on the Growth Performance of Cyprinus carpio Fry. IOSR-JAVS, 4: 34-37.

Mondal, K and Payra, P., 2015. A Review on use of Plant Protein Sources in Diets for Fish Feed Formulation. Journal of International Academic Research for 
Multidisciplinary, 3(5): 257-264.

Mondal, K., Kaviraj, A. and Mukhopadhyay, P.K., 2012. Effects of partial replacement of fishmeal in the diet by mulberry leaf meal on growth performance and digestive enzyme activities of Indian minor carp Labeo bata. International Journal of Aquatic Science, 3(1): 72-83.

Munguti, J.M., Liti, D.M., Waidbacher, H., Straif, M. and Zollitsch, W., 2006. Proximate composition of selected potential feedstuffs for Nile tilapia (Oreochromis niloticus Linnaeus) production in Kenya.

Mzengereza, K., Msiska, O.V., Kapute, F., Kang'ombe, J., Singini, W. and Kamangira, A., 2014. Nutritional Value of Locally Available Plants with Potential for Diets of Tilapia Rendalli in Pond Aquaculture in NkhataBay, Malawi. Journal of Aquaculture Research \& Development, 5(6), pp.1.

Ng, W.K. and Wee, K.L., 1989. The nutritive value of cassava leaf meal in pelleted feed for Nile tilapia. Aquaculture, 83(1-2): 45-58.

NRC (National Research Council) (1993) Nutrient Requirements of Fish. National Academy Press, Washington, DC. pp. 124.

Nsofor, C.I., Igwilo, I.O., Avwemoya, F.E. and Adindu, C.S., 2012. The effects of feeds formulated with Moringa oleifera leaves in the growth of the African Catfish, Clarias gariepinus. Res. Rev. Biosci, Pp. 121-126.

Obwanga, B.O., 2010. The Efficacy of Selected Plant Materials in Formulated Diets for Nile Tilapia, Oreochromis niloticus (L)(Master's thesis).

Olvera-Novoa, M. A., Campos, S. G., Sabido, M. G. and Palacios, C. A. M. 1990. The use of alfalfa leaf protein concentrates as a protein source in diets for tilapia (Oreochromis mossambicus). Aquaculture, 90(3-4): 291-302.

Onim, J.F.M., Ochola, P., Mathuva, M., Otieno, K. and Fitzhugh, H.A., 1987. Dry matter, nitrogen and green manure yields of Leucaena, Sesbania and pigeonpea in a cutting frequency study. In Proceedings of 6th KUA/SRCRSP Kenya Workshop (pp. 65-71).

Osman, M.F., Omar, A.E. and Nour, A.M., 1996. The use of leucaena leaf meal in feeding Nile tilapia. Aquaculture international, 4(1): 9-18.

Oyenuga, V.A., 1968. Nigeria's food and feedstuffs. Their Chemistry and nutritive value. 3rd edition, Ibadan Uni. Press, Ibadan. pp.99.

Panda, S.K., Sahu, B.K. and Panda, N.C., 1988. Nutritive Value of Agasti (Sesbania grandiflora) Leaves in Goats. Indian Journal of Animal Nutrition, 5(1): 68-69.

Pantastico, J.B. and Baldia, J.P., 1979. Supplemental feeding of Tilapia mossambica. In Proceedings of a World Symposium on Finfish Nutrition and Fishfeed Technology, Hamburg 20-23 June, 1978, pp. 587-593.

Patel, B.M., 1966. A review of work done from 1961 to 1965 at Anand. Indian Council of Agricultural Research.

Patnaik, S., Swamy, D.N., Rout, M. and Das, K.M., 1991, January. Use of ottelia and nymphoides leaf meal as protein source in the feed of indian major carp fry. In Anonymous Proceedings of the National Symposium on New Horizons in Freshwater Aquaculture: 23-25.

Phuc, B.H.N., Ogle, B. and Lindberg, J.E., 2000. Effect of replacing soybean protein with cassava leaf protein in cassava root meal based diets for growing pigs on digestibility and $\mathrm{N}$ 
retention. Animal Feed Science and Technology, 83(3): 223-235.

Preston, T.R., 2006. Forages as protein sources for pigs in the tropics. $\mathrm{CAB}$ Reviews: Perspectives in Agriculture, Veterinary Science, Nutrition and Natural Resources, 1(046).

Ravidran, V., 1991. Preparation of cassava leaf products and their use as animal feeds. Proceedings of the FAO Expert Consultation, CIAT, Cali, Colombia, pp.81-95.

Ray, A.K. and Das, I.S.I.T.A., 1994. Apparent digestibility of some aquatic macrophytes in rohu, Labeo rohita (Ham.) fingerlings. Journal of Aquaculture in the Tropics, 9(4): 335342.

Ray, A.K. and L. Das, 1995. Evaluation of dried aquatic weed, Pistia stratoides meal as a feed stuff in pelleted feed for rohu, Labeo rohita fingerlings. J. Applied Aquacul., 5: 35-44.

Richter, N., Siddhuraju, P. and Becker, K. 2003. Evaluation of nutritional quality of Moringa (Moringa oleifera Lam.) leaves as alternative protein source for tilapia (Oreochromis niloticus L.). Aquaculture. 217: 599-611.

Rodriguez, S.M., N.M.A. Olvera and O.C. Carmona, 1996. Nutritional value of animal by product meal in practical diets for Nile Tilapia, Oreochromis niloticus (L) fry. Aquaculture Res., 27: 67-73.

Rumsey, G.L., Hughes, S.G. and Winfree, R.A., 1993. Chemical and nutritional evaluation of soya protein preparations as primary nitrogen sources for rainbow trout (Oncorhynchus mykiss). Animal feed science and technology, 40(2-3): 35151.

Saint-Paul, U., Werder, U., and Teixeira, A.S., 1981. Use of water hyacinth in feeding trials with Matrinchã (Brycon sp.). Journal of Aquatic Plant Management, 19:18-22.

Santiago, C.B., Aldaba, M.B., Reyes, O.S. and Laron, M.A., 1988. Response of Nile tilapia (Oreochromis niloticus) fry to diets containing Azolla meal. In International Symposium on Tilapia in Aquaculture, 2: 377-382.

Shelton, H.M. and Gutteridge, R.C. eds., 1998. Forage tree legumes in tropical agriculture. Tropical Grassland Society of Australia.

Sklan D, Prag T and Lupatsch I, 2004. Apparent digestibility coefficients of feed ingredients and their prediction in diets for tilapia Oreochromis niloticus $\times$ Oreochromis aureus (Telepstei, Cichlidae). Aquacult. Res., 35: 358364.

Sotolu, A.O. and Faturoti, E.O., 2008. Digestibility and nutritional values of differently processed Leucaena leucocephala (Lam. de Wit) seed meals in the diet of African catfish (Clarias gariepinus).

Stott, B. and Orr, L.D., 1970. Estimating the amount of aquatic weed consumed by grass carp. The Progressive FishCulturist, 32(1): 51-54.

T.P. Sheeno and N.P. Sahu, 2006. Use of Freshwater Aquatic Plants as a Substitute of Fishmeal in the Diet of Labeo rohita Fry. Journal of Fisheries and Aquatic Science, 1: 126-135.

Tagwireyi, T., Mupangwa, J.F., Jepsen, J. and Mwera, P., 2012. Effect of feeding Moringa oleifera leaf meal on the growth performance of Oreochromis niloticus fry.

Tantikitti, C., Rittibhonbhun, N., Chaiyakum, K. and Tansakul, R., 1988. Economics of tilapia pen culture using various feeds in Thale Noi, Songkhla Lake, Thailand. In ICLARM Conference Proceedings (Philippines). ICLARM.

Vhanalakar, S.A and Muley, D.V., 2015. 
Evaluation of Medicago sativa leaf powder as supplementary feed for the growth of Fish, Cirrhinus mrigala. Bioscience Discovery, 6(1-I) Special, April - 2015.

Vhanalakar, S.A., 2009. Growth response of Cirrhina mrigala and Cyprinus Carpio to plants formulated diets as protein source.

Wee K.L. 1991. Use of non-conventional feedstuffs of plant origin as fish feeds. is it practical and economically feasible? pp. 13-32. In: De Silva S.S. (ed.) Fish nutrition research in Asia. Proceedings of the fourth Asian fish nutrition workshop. Asian Fisheries Society, Special Publication No. 5, Manila.

Wersal, R.M. and Madsen, J.D., 2012. Aquatic plants their uses and risks. A review of the global status of aquatic plants. Rome, Italy: FAO.

Yilmaz, E., A. Şahin, M. Duru and I. Akyurt.
2005. The effect of varying dietary energy on growth and feeding behaviour of common carp, Cyprinus carpio, under experimental conditions. Appl. Ani. Behav. Sci., 92 (1-2): 8592.

Yousif, O.M., Alhadrami, G.A. and Pessarakli, M., 1994. Evaluation of dehydrated alfalfa and salt bush (Atriplex) leaves in diets for tilapia (Oreochromis aureus L.). Aquaculture, 126(3-4): 341-347.

Yuangsoi, B. and Masumoto, T., 2012. Replacing moringa leaf (Moringa oleifera) partially by protein replacement in soybean meal of fancy carp (Cyprinus carpio). Songklanakarin Journal of Science \& Technology, 34(5).

Zolotova, Z.K. and L.V. Khromov, 1970 The weeding role of grass carp. Rybovod. Rybolov., 1970(4):8

\section{How to cite this article:}

Dorothy, M.S., Sudhanshu Raman, Vipin Nautiyal, Khushvir Singh, T. Yogananda and Makamguang Kamei. 2018. Use of Potential Plant Leaves as Ingredient in Fish Feed-A Review. Int.J.Curr.Microbiol.App.Sci. 7(07): 112-125. doi: https://doi.org/10.20546/ijcmas.2018.707.014 